\title{
BICRA wt Allele
}

National Cancer Institute

\section{Source}

National Cancer Institute. BICRA wt Allele. NCI Thesaurus. Code C54276.

Human BICRA wild-type allele is located in the vicinity of $19 q 13.33$ and is approximately 95 $\mathrm{kb}$ in length. This allele, which encodes BRD4-interacting chromatin-remodeling complexassociated protein, plays a putative role in the inhibition of cell growth. The chromosome region that includes this gene is frequently deleted in gliomas. 